\title{
THE PROSPECTS FOR THE SURVIVAL OF THE POPULATION OF A BOREAL RELICT SPECIES, Betula humilis Schrk., IN A SMALL ISOLATED PEAT BOG IN THE ŁECZNA - WLODAWA LAKELAND
}

\author{
Magdalena Pogorzelec, Joanna Wojciechowska \\ Department of General Ecology, University of Life Sciences in Lublin, Akademicka 13, 20-950 Lublin, Poland \\ e-mail: magdalena.pogorzelec@up.lublin.pl
}

Received: 02.12.2010

\begin{abstract}
An attempt was made to identify the major risks to the population of Betula humilis Schrk. existing in a small isolated transitional peat bog near Lake Bikcze, in the Łęczna-Włodawa Lakeland. The biometric features of 40 Betula humilis individuals were measured as well as the growth of shoots, flowering and fruiting were observed. Habitat conditions were characterized by making measurements of selected abiotic and biocenotic environmental factors. The obtained results allowed us to identify two main threats to the proper functioning of the study population. The first one is the possible loss of genetic identity of the species as a result of probable ongoing introgression by the potential crossing of Betula humilis with other species of the genus Betula, which are numerous in the flora of the studied area. Another threat is a change in habitat conditions (mainly light and water conditions), which is due to the accelerated secondary succession manifested by the expansion of common species such as Salix cinerea, Betula pendula, and Phragmites australis.
\end{abstract}

Key words: Betula humilis, biometric features, threats, habitat conditions

\section{INTRODUCTION}

Transitional and raised peat bogs are among the most valuable natural sites of the Łęczna-Włodawa Lakeland. They are characterized by the presence of plant species with the so-called narrow ecological spectrum (Fijałkowski, 1991). These species, which are often relict, rare and protected species, are also found in the flora of the transitional peat bog adjacent to the western shore of Lake Bikcze (Pogorzelec and $\mathrm{B}$ a n a c h, 2008).

Lake Bikcze is located in the south eastern part of the Łęczna-Włodawa Lakeland, $51^{\circ} 22^{\prime} \mathrm{N}$ longitude $23^{\circ} 03^{\prime} \mathrm{E}$ latitude. In the past, it was a flow-through lake, fed and drained by the Piwonia river. Currently, it is surrounded by a drainage ditch and an embankment on its western side and functions as a storage reservoir (W o j c i e c how s ki, 1979). The space between the reservoir water-table and the embankment is covered by a transitional peat bog.

A part of this peat bog, especially from the western and northern sides, undergoes succession by the intensive development of plant communities with $\mathrm{Sa}$ lix cinerea and the encroachment of species such as Betula pendula and Phragmites australis, which has a significant influence on the change in habitat conditions in this area (primarily water and light conditions). It determines the withdrawal of species specific to bog flora, including the so-called "special concern" species (Lorens et al. 1998; Pogorzelec and $\mathrm{B}$ an a ch, 2008).

One of the relict plant species is the rare and protected Betula humilis, a highly branched shrub that reaches a height of 0.5 to $2.0 \mathrm{~m}$. Betula humilis is an anemophilous, monoecious plant with dioecious flowers (Bi oń ska, 1974; S taszkiewicz et al. 1991). Betula humilis can create hybrids with other birch species: Betula pendula, $B$ pubescens, and B. nana (P i ękoś-M irkow a and Mirek, 2003).

Betula humilis is a late-glacial relict which came to Central Europe from the north in the Pleistocene. The geographical range of Betula humilis includes Eastern Europe and the central part of Europe. In isolated stands, it also grows in the foothills of the Alps, in south-western Germany, northern Switzerland as well as in the eastern and southern Carpathians. Outside Europe, Betula humilis extends its range to the Altai Mountains, beyond Baikal, northern China, reaching as far as the Sea of Okhotsk. A narrow strip along the Yenisei River reaches into the Arctic Circle 
(B i ońs ka 1974; Zału ski et al. 2001; Pięk oś- Mirkowa and Mirek, 2003).

In Poland Betula humilis reaches the south-western border of the compact range. Its stands are grouped in the northern and eastern parts of the country in Western Pomerania, Masurian Lakeland, Podlasie, and the northern Lublin region. Small numbers can be found in dispersion in the western and eastern Great Poland, Lubusz Land, in Mazovia, and northern Galicia.

Betula humilis is a species that is withdrawing from its stands. In Poland there were more than 350 sites recorded in the past, while only about 70 were recently confirmed. The current number of natural stands confirmed in the Lublin Region is 20 ( $\mathrm{J}$ a s n ow s k i , 1955; S o c z ew s ka, 2000; Z a ł u ski et al. 2001).

Betula humilis is one of three species of the genus Betula that are legally protected in Poland.

The progressive disappearance of Betula humilis stands is the result of large-scale drainage of wetlands, their too intensive use as hay meadows and pastures, the conversion of grassland to farmland and its reforestation, as well as peat extraction $(\mathrm{Z}$ a ł u s k i et al. 2001; J a snowski, 1955; Pię k oś-Mirkowa and Mirek 2003; Pi ękoś-Mirkowa, 2006).

This work aims to characterize the populations of Betula humilis against the background of their habitat conditions in one of the stands in a small isolated peat bog in the Łęczna-Włodawa Lakeland, and it is an attempt to identify threats that may have a significant impact on the further functioning of the study population in that area.

\section{MATERIALS AND METHODS}

A field study was conducted in the period 2007 2009 in a transitional peat bog adjacent to the western shore of Lake Bikcze, in the Łęczna-Włodawa Lakeland (Fig. 1).

The first stage of the study was to explore this area on foot; this was aimed to initially identify the location and number of Betula humilis specimens in the peat bog.

5 study plots of $100 \mathrm{~m}^{2}$ in area were selected. The selection of the plots was dependent on the abundance and distribution of Betula humilis individuals, but also on the diversity of phytoceonoses and habitat conditions. The number of Betula humilis individuals was identified for each plot. Biometric measurements were made on 40 shrubs that grew within the plots, including the following: plant height $(\mathrm{cm})$, two diameters of each shrub, number of properly developed shoots, number of leaves of a shoot with medium length, length and width of the largest of the first three leaves that were located in the upper part of the representative shoot. Biometric measurements of the same shoot were repeated each year; the examined specimens were marked with tags (leaf measurements were made in 2008-2009).

Observations were conducted of flowering and fruiting individuals of Betula humilis at the study sites.

Selected abiotic environmental factors were measured repeatedly: ground water level $(\mathrm{cm}$; with a ruler), acidity ( $\mathrm{pH}$, using a field battery-operated $\mathrm{pH}$-meter), electrolytic conductivity $\left(\mu \mathrm{S} \times \mathrm{cm}^{-3}\right.$, using a field battery-operated conductometer), in the upper layer of groundwater and the degree of shading of the bog surface $(\%)$ by the trees in each plot.

Detailed lists of vascular flora species in the plots were also prepared in 2008. The species occurring in the investigated phytocoenoses were identified using the key of Rutkowski (1998), species nomenclature, Polish and Latin, followed Mi r e k et al. (2002), the assignment of particular species to syntaxonomic units followed Matuszkiewicz (2005). During office investigations, Ecological indicator values of vascular plants of Poland (Zarzycki et al. 2002) was also used to determine specific habitat conditions, based on the affinity of plant species of particular phytocoenoses with characteristic ecological groups.

\section{RESULTS}

The Betula humilis population around the peat bog numbered about 100 individuals (bushes). Altogether, 40 Betula humilis individuals grew within the study area (study plot no. 1-10 individuals, no. 2-6 individuals, no. 3-1 individuals, no. 4-5 individuals, no. 5-8 individuals). Measurements taken on the Betula humilis individuals located within the study area confirmed the high diversity of biometric features of plants (Table 1.) The height and diameter of the shrub determined the number of leaves of the examined individuals. Shrubs over $100 \mathrm{~cm}$ in height had a greater number of leaves. The examined shoots grew from 0 to $80 \mathrm{~cm}$ per year. All specimens bloomed and bore fruit. During the analysis of floristic inventories in the study area, 54 species of vascular plants belonging to 27 botanical families (the family Cyperaceae was the most numerous -8 species) and 11 syntaxonomic classes were recorded altogether (the most abundant class was Alnetea glutinosae - 21 species).

Betula humilis co-occurred with vascular plant species such as Betula pendula, Calamagrostis canescens, Equisetum fluviatile, Oxycoccus palustris, Thelypteris palustris (Table 2) in the studied area. During the years of the study, the species composition of the flora did not change.

The vast majority in the phytocoenosis of the peat bog were species characteristic of moderately warm and moderately cool climatic conditions. 
The flora was dominated by plant species that prefer moderate light at their sites (including Betula humilis). Both the field observations and flora analysis indicated a predominant proportion of wet soil plants, but also moist and fresh soil plants. The flora of the studied area was dominated by species preferring moderately poor (mesotrophic) and rich soils (eutrophic) with a neutral or a slightly acidic $\mathrm{pH}(5-6)$. The largest group consisted of species that prefer humid habitats (Table 3 ).

In the peat bog near Lake Bikcze, a significant increase was observed in the level of groundwater in all the plots between the years 2007 and 2009; this probably resulted in a rise in groundwater acidity values (Table 4).

Table 1

Biometric features of selected (40) specimens of Betula humilis examined in 2007-2009.

\begin{tabular}{|c|c|c|c|c|c|c|c|c|c|c|c|c|c|}
\hline \multicolumn{2}{|c|}{ Examined feature } & \multicolumn{3}{|c|}{ Mean value } & \multicolumn{3}{|c|}{ Median } & \multicolumn{3}{|c|}{ Min. } & \multicolumn{3}{|c|}{ Max. } \\
\hline Year & & 2007 & 2008 & 2009 & 2007 & 2008 & 2009 & 2007 & 2008 & 2009 & 2007 & 2008 & 2009 \\
\hline Plant height $(\mathrm{cm})$ & & 110.0 & 120.0 & 120.0 & 90.0 & 120.0 & 120.0 & 40.0 & 30.0 & 40.0 & 180.0 & 200.0 & 200.0 \\
\hline Shrub diameter I $(\mathrm{cm})$ & & 120.0 & 80.0 & 110.0 & 100.0 & 80.0 & 100.0 & 40.0 & 10.0 & 10.0 & 490.0 & 270.0 & 220.0 \\
\hline Shrub diameter II $(\mathrm{cm})$ & & 80.0 & 60.0 & 80.0 & 70.0 & 50.0 & 80.0 & 20.0 & 10.0 & 10.0 & 200.0 & 240.0 & 220.0 \\
\hline Number of shoots & & 37.9 & 31.8 & 31.0 & 10.0 & 17.0 & 10.0 & 1.0 & 1.0 & 1.0 & 210.0 & 190.0 & 273.0 \\
\hline \multirow{3}{*}{$\begin{array}{l}\text { Number of leaves in } \\
\text { a selected shoot }\end{array}$} & All shoots & 123.8 & 89.5 & 70.0 & 119.5 & 84.5 & 59.5 & 23.0 & 11.0 & 8.0 & 285.0 & 193.0 & 253,0 \\
\hline & $>100 \mathrm{~cm}$ & 95.4 & 57.6 & 48.8 & 69.0 & 46.5 & 46.5 & 23.0 & 11.0 & 8.0 & 280.0 & 184.0 & 91,0 \\
\hline & $<100 \mathrm{~cm}$ & 161.3 & 109.6 & 97.2 & 152.0 & 102.0 & 81.0 & 57.0 & 42.0 & 31.0 & 285.0 & 193.0 & 273,0 \\
\hline A - leaf length $(\mathrm{cm})$ & & - & 2.3 & 2.0 & - & 2.3 & 2.0 & - & 1.3 & 1.3 & - & 3.5 & 2.9 \\
\hline B - leaf width $(\mathrm{cm})$ & & - & 1.8 & 1.6 & - & 1.7 & 1.6 & - & 1.0 & 0.7 & - & 2.9 & 2.3 \\
\hline$A: B$ & & - & 1.3 & 1.3 & - & 1.3 & 1.3 & - & 0.6 & 1.0 & - & 1.8 & 2.0 \\
\hline
\end{tabular}

Table 2

Species composition of vascular flora in the plots in 2008

\begin{tabular}{|c|c|c|c|c|c|c|c|c|c|c|c|}
\hline \multirow{2}{*}{ Species } & \multicolumn{5}{|c|}{ Study plot } & \multirow{2}{*}{ Species } & \multicolumn{5}{|c|}{ Study plot } \\
\hline & 1 & 2 & 3 & 4 & 5 & & 1 & 2 & 3 & 4 & 5 \\
\hline Agrostis capillaris & + & & + & & & Lycopus europaeus & + & + & + & + & \\
\hline Andromeda polifolia & + & & + & & & Lysimachia nummularia & & & & + & \\
\hline Betula humilis & + & + & + & + & + & Lysimachia thyrsiflora & & & + & & \\
\hline Betula pendula & + & + & + & + & + & Lysimachia vulgaris & + & + & + & + & \\
\hline Betula pubescens & + & + & + & + & + & Lythrum salicaria & & + & + & + & + \\
\hline Calamagrostis canescens & + & & + & & + & Menyanthes trifoliata & + & + & + & & + \\
\hline Calla palustris & & + & + & & & Oxalis acetosella & & & & + & \\
\hline Carex acutiformis & & & + & & & Oxycoccus palustris & + & & + & + & + \\
\hline Carex chordorrhiza & & & + & & & Peucedanum palustre & + & & + & + & + \\
\hline Carex elata & & & + & & & Phragmites australis & & + & & & \\
\hline Carex lasiocarpa & & & + & & & Poa pratensis & + & + & + & & \\
\hline Carex limosa & + & & + & & & Poa travialis & + & & + & & \\
\hline Carex nigra & + & & + & & + & Populus tremula & + & & + & + & \\
\hline Carex rostrata & + & & + & & + & Potentilla erecta & & & & + & \\
\hline Cicuta virosa & & & & + & + & Ranunculus lingua & + & & + & & \\
\hline Comarum palustre & + & + & + & & + & Rubus idaeus & & & & + & \\
\hline Dactylorhiza majalis & + & & & & & Salix aurita & + & & + & + & + \\
\hline Deschampsia caespitosa & & & + & & & Salix cinerea & + & + & + & + & + \\
\hline Drosera rutundifolia & + & & & & & Salix lapponum & & & + & & \\
\hline Equisetum flaviatile & + & + & + & + & + & Salix pentandra & & & + & & \\
\hline Eriophorum angustifolium & + & & & & & Salix rosmarinifolia & + & & + & & + \\
\hline Frangula alnus & & + & + & + & & Solanum dulcamara & & + & & & \\
\hline Galium palustre & + & & + & + & + & Stellaria palustris & + & & + & + & + \\
\hline Geranium palustre & & & & + & & Stellaria uliginosa & & & & & \\
\hline Geum rivale & & & & + & & Thelypteris palustris & + & + & + & + & + \\
\hline Juncus articularis & + & & + & + & + & Typha angustifolia & & & + & & \\
\hline Juncus conglomeratus & + & & + & & & Utricularia vulgaris & + & & + & & + \\
\hline
\end{tabular}


Table 3

Percentage of plant species with different habitat requirements in the phytocoenoses of the study plots (using the ecological indicator values of vascular plants) (Z a r z y ck i et al. 2002).

\begin{tabular}{lrrrrrr}
\hline & \multicolumn{5}{c}{ Indicator values } \\
\cline { 2 - 7 } \multicolumn{1}{c}{ Selected indicators } & 1 & 2 & 3 & 4 & 5 & 6 \\
\hline L - light value & 2 & 5 & 18 & 85 & 11 & 0 \\
T - temperature value & 2 & 18 & 80 & 91 & 2 & 0 \\
K - continentality value & 0 & 0 & 91 & 7 & 2 & 0 \\
W - soil moisture value & 0 & 2 & 18 & 45 & 75 & 11 \\
TR - trophy value & 5 & 16 & 67 & 56 & 2 & 0 \\
R - soil (water) acidity $(\mathrm{pH})$ value & 7 & 18 & 45 & 67 & 22 & 0 \\
H - organic matter content value & 4 & 42 & 84 & 0 & 0 & 0 \\
\hline
\end{tabular}

Table 4

Values of some abiotic factors measured in the upper layer of groundwater of the plots in 2007 and 2009.

\begin{tabular}{|c|c|c|c|c|c|c|}
\hline \multicolumn{2}{|c|}{ Date } & Plot & $\begin{array}{l}\text { Acidity } \\
(\mathrm{pH})\end{array}$ & $\begin{array}{l}\text { Electrolytic conductivity } \\
\quad\left(\mu \mathrm{S} \times \mathrm{cm}^{-1}\right)\end{array}$ & $\begin{array}{l}\text { Water level } \\
\qquad(\mathrm{cm})\end{array}$ & $\begin{array}{l}\text { Shading of the } \\
\text { bog surface }(\%)\end{array}$ \\
\hline \multirow{5}{*}{ \&્d } & \multirow{5}{*}{ 12. 07} & 1 & 4.7 & 88.4 & 7.0 & - \\
\hline & & 2 & 4.9 & 102.3 & 9.0 & - \\
\hline & & 3 & 4.4 & 64.4 & 7.0 & - \\
\hline & & 4 & 4.8 & 100.1 & 4.0 & - \\
\hline & & 5 & 5.4 & 73.6 & 7.0 & - \\
\hline \multirow{10}{*}{$\stackrel{\infty}{\stackrel{్}{े}}$} & \multirow{5}{*}{ 20. 05} & 1 & 6.7 & 134.0 & 27.0 & 20 \\
\hline & & 2 & 6.7 & 128.0 & 31.0 & 30 \\
\hline & & 3 & 6.4 & 154.0 & 28.0 & 10 \\
\hline & & 4 & 6.9 & 122.0 & 30.0 & 50 \\
\hline & & 5 & 5.6 & 117.0 & 16.0 & 20 \\
\hline & \multirow{5}{*}{ 14. 07} & 1 & 6.7 & 178.3 & 17.0 & - \\
\hline & & 2 & 6.2 & 173.0 & 16.0 & - \\
\hline & & 3 & 5.8 & 116.0 & 14.0 & - \\
\hline & & 4 & 6.6 & 124.0 & 18.0 & - \\
\hline & & 5 & 6.0 & 128.0 & 15.0 & - \\
\hline \multirow{10}{*}{ ڤ્ণ } & \multirow{5}{*}{ 16. 05} & 1 & 5.9 & 149.0 & 24.0 & 30 \\
\hline & & 2 & 6.0 & 121.0 & 18.0 & 30 \\
\hline & & 3 & 6.1 & 159.0 & 22.0 & 10 \\
\hline & & 4 & 6.6 & 156.7 & 26.0 & 50 \\
\hline & & 5 & 6.1 & 132.0 & 22.0 & 20 \\
\hline & \multirow{5}{*}{ 12. 07} & 1 & 6.3 & 53.0 & 42.1 & - \\
\hline & & 2 & 6.5 & 56.0 & 44.2 & - \\
\hline & & 3 & 6.2 & 59.0 & 35.0 & - \\
\hline & & 4 & 6.3 & 80.0 & 43.2 & - \\
\hline & & 5 & 6.7 & 122.0 & 30.0 & - \\
\hline
\end{tabular}




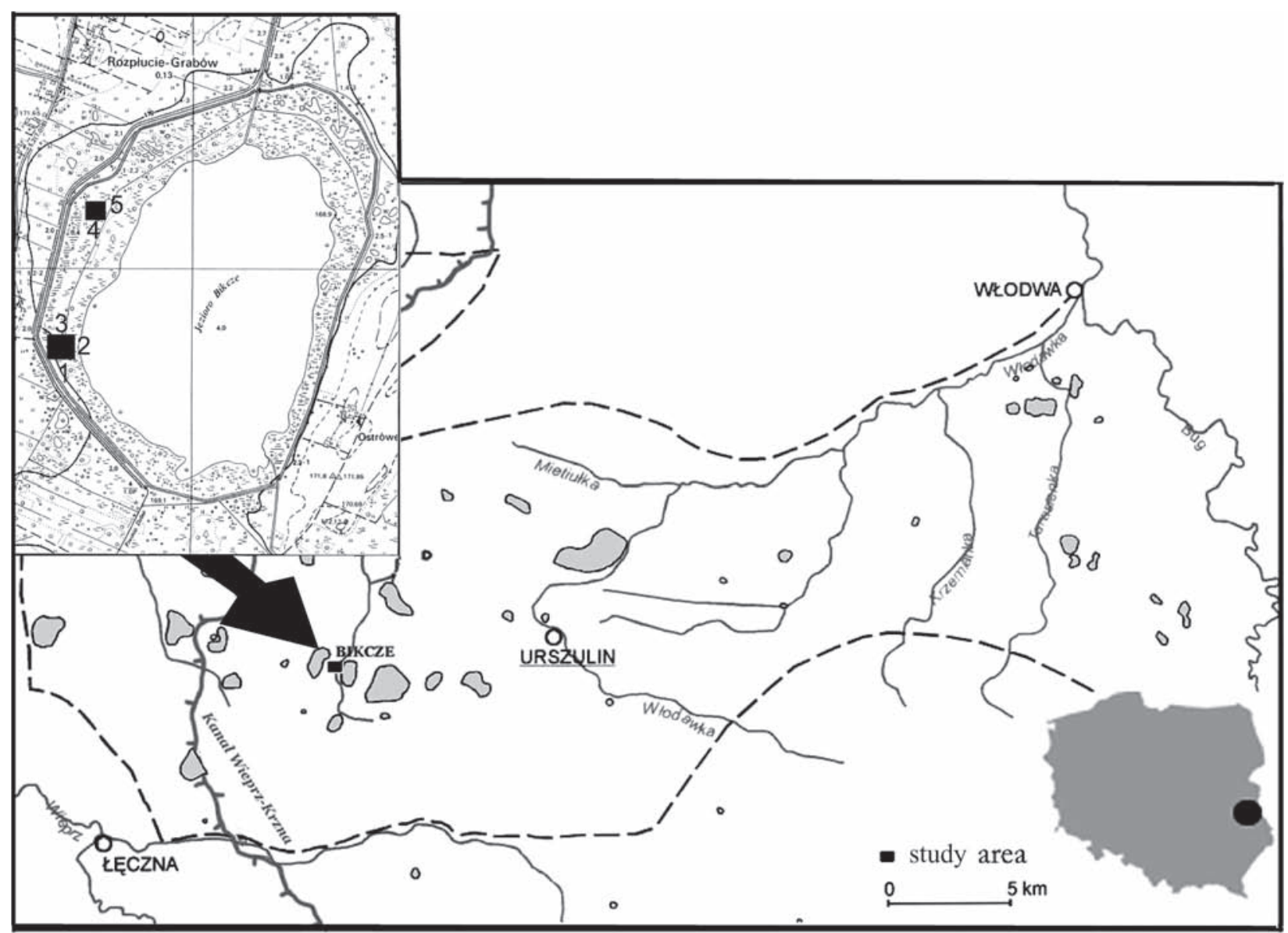

Fig. 1. Location of the study area in the Łęczna-Włodawa Lakeland.

\section{DISCUSSION}

The literature data relating to morphological diversity present Betula humilis as an extremely variable species. Rutk ow s ki (1998) gives the average height of a Betula humilis shrub in the range of $30-80 \mathrm{~cm}$ (max. $120 \mathrm{~cm})$. B o i ń s k a [1974] reported that various individuals in Northern Poland clearly differed from each other in their height: from about $50 \mathrm{~cm}$ (Koszelewki fen) to about $300 \mathrm{~cm}$ (Cielętnik mire). In 1998, Endler and Duriasz described that the highest bushes of Betula humilis in the Zabrodzie Reserve (the central part of Lake Mrągowo) grew to $160 \mathrm{~cm}$, and the height of the most common individuals ranged from 70 to $120 \mathrm{~cm}$.

According to Matowicka and Jabłons k a (2008), Betula humilis specimens measured from several to $200 \mathrm{~cm}$ in Poland (sometimes 300-400 cm). In the present author's study conducted in 20072009 on Lake Bikcze, it was found that the height of specimens ranged from $33 \mathrm{~cm}$ to $200 \mathrm{~cm}$. The studied trait was probably determined by the availability of light in the habitat and the age of specimens.

In $1968 \mathrm{Fijałkowski}$ presented the results of measurements of leaf length in the examined species as ranging from 1 to $3.5 \mathrm{~cm}$. In all the samples taken from low birch trees in northern Polish, the values of morphometric features of the leaves, irrespective of the type of the shoot from which they came, ranged as follows: lamina length - from 0.8 to $4.6 \mathrm{~cm}$, lamina width - from 0.4 to $3.3 \mathrm{~cm}$, and the ratio of leaf length to width ranged from 0.7 to 2.5 ( $\mathrm{B}$ i o ń s k a, 1974).

According to Staszkiewicz (1991), the length of $B$. humilis leaf blade (in specimens examined at 13 sites in Poland) reached from 0.8 to $4.4 \mathrm{~cm}$. This corresponded, more or less, to the values determined for northern Poland (B o i ń s k a , 1974) and to the values determined during the present author's study conducted in 2007-2009 in the peat bog near Lake Bikcze.

The analysis of the length, width, and ratio of length to width of Betula humilis leaf may indicate that the cause of a wide range of variability of these features in local floras could be the presence of interspecific hybrids. The huge variability within the species is due not only to environmental conditions, but is mostly dependent on the genetic characteristics of individuals, as evidenced in the research of $\mathrm{Stas} \mathrm{z} \mathrm{kie} \mathrm{wic} \mathrm{z}$ et al. (1991a). It is known that Betula humilis often crosses with other native species of birch such as Betula 
pendula and B. pubescens, which often co-occur with the study species in natural stands (Pię k oś-Mirk ow a and Mirek, 2003).

In the peat bog near Lake Bikcze, the occurrence of numerous species (Betula pendula, Betula pubescens) potentially hybridizing with Betula humilis was noted. Introgression (the gene flow between the crossing populations), which causes gradual loss of genetic identity of the species, may in future be one of the factors threatening the existence of the Betula humilis population in this area.

Betula humilis was found in many types of phytocoenoses. It was a component of such classes of plant associations as Alnetea glutinosea and Phragmitetea (Endler and Durians, 1998; Sienkiewicz- $\mathrm{P}$ a d e r e w s k a , 2007), but it also often occurred in associations of the class - Scheuchzerio-Caricetea nigrae (P o lak ow sk i, 1962; Fi jałk ow ski, 1994; Endler and Durians, 1998; Z ałuski, 2001). Betula humilis is a typical species for low shrubs of Betulo-Salicetum repentis occurring in transitional peat bogs and in many sites in Poland it is a component of such phytocoenoses (F i j ł k ow s ki, 1968; B oińska, 1974; Endler and Durians, 1998; Matuszkiewicz 2001; Załuski et al. 2001; Piękoś-Mirkowa and Mirek 2003; Sienkiewicz-Pederewska 2007; Matowicka and $\mathrm{J}$ a błoń ska, 2008).

Betula humilis was classified as a photophilous species (Z a r z y c k i et al. 2001; Pi ę k o ś- M irkowa and Mirek, 2003; Zych and Werblan- J a kubi ec, 2005; Pi ękoś-Mirkowa, 2006; Matowicka and Jabłońska, 2008). Jabłońska and Pawlikowski (2004) as well as Matow i cka and Jabłońska (2008) proved that the succession progressing towards forest communities, thereby increasing shading, may contribute to a gradual decrease in the population size of birch and thus the disappearance of stands of this species.

During the original field investigations, it was noted that the flora of the peat bog near Lake Bikcze was dominated by taxa that were characteristic for classes such as Alnetea glutinosae, Scheuchzerio-Caricetea nigrae, Oxycocco-Sphagnetea, Phragmitetea. The peat bog phytocoenosis was characterized by a high proportion of expansive plant species. A strong competition from woody vegetation in the future may be another threat to the proper functioning of the population. In the peat bog near Lake Bikcze, a progressive process of ecological succession has been observed for many years. It manifests itself mainly by the encroachment of plant communities dominated by Salix cinerea and Betula pendula into the peat bog (L o r e $\mathrm{n} \mathrm{s}$ et al. 1998; P o g o r z e le c, 2009).

According to $\mathrm{Z}$ ałuski et al. (2001), Betula humilis growing in Poland prefers slightly acidic so- ils, rarely a strongly acidic or neutral soil $\mathrm{pH}$, and sometimes even an alkaline $\mathrm{pH}$ in carbonate peat bogs (pH 4.7-7.3). However, Z a r z y c ki et al. (2002) found that an optimal $\mathrm{pH}$ for Betula humilis was a neutral soil $\mathrm{pH}$.

The $\mathrm{pH}$ of groundwater examined in situ in the studied sites in 2007-2009 ranged from acidic to slightly acidic. The habitat analysis based on selected ecological indicator values for vascular plants co-occurring in the examined habitat of Betula humilis proved that the flora was dominated by species preferring a neutral and slightly acidic $\mathrm{pH}$. The results of measurements of the highest groundwater layer presented in this study showed that from 2007 it continually increased and reached its highest value in July 2009. The part of the peat bog near Lake Bikcze inhabited by Betula humilis is a hydrated area where ground water is above the ground level for most of the growing period.

During the study carried out in 2007-2009, the parameters of the selected habitat conditions within the peat bog area were appropriate for the preferences of the studied species. The Betula humilis individuals bloomed, bore fruit and quickly grew in length as well as they increased the number of their shoots, which additionally confirmed the viability of the population at the studied site. But it is difficult to predict how long the population will survive in the study area due to the fact that the bog area is not protected by any nature conservation form. Active protection, consisting in the removal of expansive species, could inhibit the progressive natural succession in the peat bog, and thus allow for the continuation of the preferred habitat conditions of Betula humilis.

It is advisable to continuously monitor the population of Betula humilis in the peat bog near Lake Bikcze because of the need to maintain this precious species and the possibility of early detection of direct and indirect threats that may affect the size and health of this population.

\section{REFERENCES}

Bi oń s k a U., 1974. Zmienność liści, owoców i łusek Betula humilis Schrk. w północnej Polsce./ Variability of the leaves, fruits and scales of Betula humilis Schrk. in north Poland. Stud. Soc. Scient. Torun. D, 9 (6): 1-108.

Endler Z., Durias z J., 1998. Brzoza niska Betula humilis w rezerwacie przyrody „Zabrodzie”./ Betula humilis in the nature reserve "Zabrodzie" Chronmy Przyrodę Ojczystą, 4: 74-77.

Fijałkowski D., 1968. Zmienność brzóz Betula L. w województwie lubelskim./ Variability of Betula L. birches in the Lublin Province Ann. UMCS, sect. C, XXII, 23: 371-379.

Fijałkowski D., 1991. Zespoły roślinne Lubelszczyzny. Wydawnictwo UMCS, Lublin (in Polish). 
Fijałkowski D., 1994. Flora roślin naczyniowych Lubelszczyzny. T. 1, 2. Lubelskie Tow. Nauk., Lublin (in Polish).

Jabłońska E., Pawlikowski P., 2004. Betula humilis Schrank in the "Całowanie" fen - distribution dynamics, habitat changes and survival chances of the species in degraded peatland. Teka Kom. Ochr. Kszt. Środ. Przyr. Vol. 1: 83-88.

Jasnowski M., 1955. Stanowiska Brzozy niskiej (Betula humilis Schrank) w dorzeczu Tyśmiennicy na Lubelszczyźnie./ The localities of Betula humilis Schrank in the Tyśmiennica river basin in the Lublin region. Ochr. Przyr, 23: 204-212 (in Polish).

Lorens B., Grądziel T., Sugier P., 1998. Zmiany roślinności w ekotonie woda - ląd jeziora Bikcze w latach 1993-1998,/ Changes in vegetation in the waterland ecotone of Bikcze Lake in 1993-1998 [In:] S. Radwan (ed.): Ekotony słodkowodne - struktura - rodzaje - funkcjonowanie. Wydawnictwo UMCS, Lublin (in Polish).

Matowicka B. i Jabłońska E., 2008. Ochrona populacji brzozy niskiej Betula humilis (Betulaceae) na Nizinie Północnopodlaskiej. [In:] K. Kolanko (ed.): Różnorodność badań - 50 lat Białostockiego Oddziału Polskiego Towarzystwa Botanicznego 1958-2008. Agencja Wydawniczo-Edytorska EkoPress, Białystok (in Polish).

Mat us zki ew ic z W., 2001. Przewodnik do oznaczania zbiorowisk roślinnych Polski. Państwowe Wydawnictwo Naukowe, Warszawa (in Polish).

Mirek Z., Piękoś-Mirkowa H., Zając A., Zając M., 2002. Flowering plants and pteridophytes of Poland. A checklist. W. Szafer Institute of Botany, Polish Academy of Sience, Kraków.

Piękoś-Mirkowa H., 2006. Flora Polski. Rośliny chronione. Wyd. Multico, Warszawa (in Polish).

Piękoś-Mirkowa H., Mirek Z., 2003. Flora Polski. Atlas roślin chronionych. Wyd. Multico, Warszawa (in Polish).

Pogorzelec M., Banach B., 2008. The occurrence of rare and protected plant species in the peat bog on Lake Bikcze (Łęczna-Włodawa Lakeland). Acta Agrobot. 61 (2): 113-120.

Pogorzelec M., Czernaś K., 2009. The phytocoenoses of differential habitats on peat bog near Lake Bikcze (Łęczna-Włodawa Lakeland). Teka Kom. Ochr. Kszt. Środ. Przyr. OL PAN, 5.

Polakowski B., 1962. Ochrona ginących gatunków torfowiskowych na Pomorzu Wschodnim. / Protection of endangered species of bog in Eastern Pomerania. Ochr. Przyr. 28: 137-157 (in Polish).

Rutkowski L., 1998. Klucz do oznaczania roślin naczyniowych Polski niżowej. Państwowe Wydawnictwo Naukowe, Warszawa (in Polish).

Soczewska B ., 2000. Nowe stanowiska rzadszych gatunków roślin naczyniowych w mezoregionie Zaklęsłość
Łomaska (wschodnia Polska). / New stands of rare vascular plant species in the mesoregion Zaklęsłość Łomaska (eastern Poland). Fragm. Flor. et Geobot. Polonica, 7: 81-91 (in Polish).

Staszkiewicz J., Białobrzeska M., Truchanowicz J. and Wójcicki J.J., 1991a. Variability of Betula humilis (Betulaceae) in Poland. 1. Variability of the leaves. Fragm. Flor. Geobot. 36 (2): 347-373.

Wojciechowski I., 1979. Wpływ zlewni na eutrofizację a-mezotroficznego jeziora Piaseczno i na deeutrofizację stawowego jeziora Bikcze / Influence of the drainage basin on the eutrophication of the a-mesotrophic Lake Piaseczno and de-eutrophication of the pond Lake Bikcze. Acta Hydrobiol. 18: 23-52, Kraków (in Polish).

Załuski T., Pisarek W., Kucharczyk M., Kamińska A.M., 2001. Betula humilis Schrank. Brzoza niska, [In:] R. Kazimierczakowa, K. Zarzycki (eds): Polska Czerwona Księga Roślin Paprotniki i rośliny kwiatowe. Instytut Bot. PAN, Inst. Ochr. Przyr. PAN, Kraków: 79-81 (in Polish).

Zarzycki K., Trzcińska-Tacik H., Różański W., Szeląg Z., Wołek J., Korzeniak U., 2002. Ecological indicator values of vascular plants of Poland. W. Szafer Institute of Botany, Polish Academy of Science, Kraków.

Zych M., Werblan-Jakubiec H., 2005. Nowe stanowisko Betula humilis (Betulaceae) na północno-wschodnim Mazowszu./ New stands of Betula humilis (Betulaceae) in the north-eastern Mazowsze region. Fragm. Flor. Geobot. Polonica - A. 12 (1): 171-173 (in Polish).

\section{Perspektywy przetrwania populacji reliktu borealnego Betula humilis Schrk. na niewielkim izolowanym torfowisku na Pojezierzu Łęczyńsko-Włodawskim}

\section{Streszczenie}

Podjęto próbę określenia najważniejszych zagrożeń dla populacji Betula humilis Schrk. egzystującej na niewielkim, izolowanym torfowisku przejściowym nad jeziorem Bikcze, na Pojezierzu Łęczyńsko-Włodawskim. Przeprowadzono pomiary biometryczne 40 osobników brzozy niskiej oraz obserwacje przyrostu pędów, kwitnienia i owocowania. Scharakteryzowano również tło siedliskowe prowadząc pomiary wybranych czynników abiotycznych i biocenotycznych środowiska. Otrzymane wyniki pozwoliły na wyróżnienie dwóch głównych zagrożeń dla prawidłowego funkcjonowania badanej populacji. Pierwszym z nich jest możliwa utrata genetycznej tożsamości gatunku, będąca wynikiem prawdopodobnej introgresji zachodzącej przez potencjalne krzyżowanie się Betula humilis z innymi gatunkami z rodzaju 
Betula, które licznie występują we florze badanego terenu. Drugim zagrożeniem jest zmiana warunków siedliskowych (przede wszystkim świetlnych i wodnych), która jest wynikiem przyspieszonej sukcesji wtórnej objawiającej się ekspansją gatunków pospolitych tj. Salix cinerea, Betula pendula i Phragmites australis. 